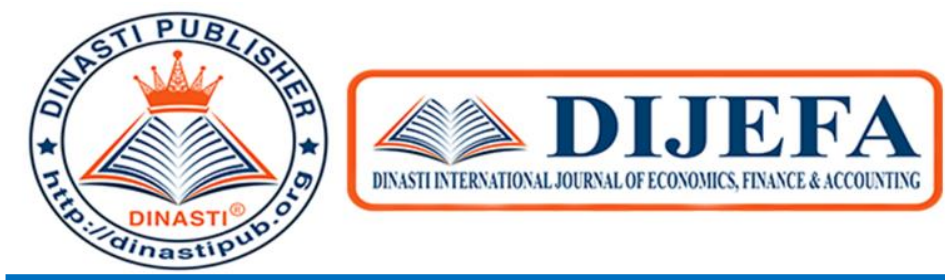

+6281387654578 (9)

+6281387654578 (Q)

https://dinastipub.org/DIJEFA (2)

dinasti-info@gmail.com (๑)

\title{
EFFECT OF PROFITABILITY, LEVERAGE, AND LIQUIDITY TO THE FIRM VALUE
}

Markonah Markonah ${ }^{1)}$, Agus Salim ${ }^{2)}$, Johanna Franciska ${ }^{3)}$

${ }^{1,2}$ Lecture of Faculty of Economics and Business, Perbanas Institute, 12940, Jakarta, Indonesia

${ }^{3}$ Student of Management, Faculty of Economics and Business,Perbanas Institute, 12940, Jakarta, Indonesia

ARTICLE INFORMATION

Received: $10^{\text {th }}$ March 2020

Revised: $17^{\text {th }}$ March 2020

Issued: $25^{\text {th }}$ April 2020

Corresponding author:

Markonah Markonah

E-mail:

markonah@perbanas.id

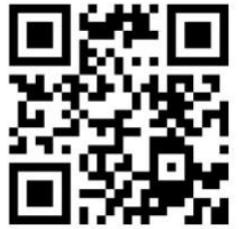

DOI:10.31933/DIJEFA
Abstract: This study aims to determine the effect of profitability (ROA), leverage (DER) and liquidity $(\mathrm{CR})$ on corporate value (PBV) in food and beverage manufacturing companies listed on the Jakarta Stock Exchange. Research Methodology research uses the data panel regression analysis method with the model used is fixed effect. The results of the F test show that profitability (ROA), leverage (DER), and liquidity (CR) adequately explain the influence on firm value (PBV). Result of research show that profitability (ROA) and leverage (DER) have significant effect to company value variable (PBV) while variable of liquidity (CR) has no significant effect to company value variable $(\mathrm{PBV})$. The results of Determination Coefficient Test showed that the proportion influence of profitability, leverage and liquidity to company value was $86 \%$. While the rest of $14 \%$ influenced by other variables.

Keywords: Return on Assets (ROA), Debt to Equity Ratio (DER), Current Ratio (CR) dan Price Book Value (PBV).

\section{INTRODUCTION}

Many companies are competing to improve the quality of the company to be able to compete in the market and attract consumers. Various ways are done to be the best. The success of a company can only be achieved with good management. Therefore, to maintain the position or superiority of a company can be done by taking a variety of strategic steps are chosen appropriately. Food and beverage manufacturing companies are one of the categories of sectors that have the opportunity to grow and develop well.

The value of the firm is the price that would be paid by the prospective investor if a company is to be sold (Sartono, 2008). For investors, corporate value is an important concept because corporate value is an indicator of how the market perceives the company as a whole. 
High corporate value is the desire of the owners of the company, because with a high value menunujukkan shareholder wealth is also high. High corporate value makes high investor confidence to invest in the company.In measuring the value of a company, investors can use the financial statements of a company. These financial statements can be analyzed through financial ratios. By analyzing the financial ratios it will reflect the good or bad of a company. If the financial ratios show good performance will attract investors to invest their capital and will affect the increasing value of the company. Vice versa if the financial ratios show the performance is not good, investors will not be interested to invest capital and impact on the decline in corporate value.

One of the financial ratios to measure company value is Price to Book Value (PBV). PBV shows how far the company is able to create company value. Good companies generally have a PBV above 1, indicating a market value higher than the book value. PBV is a ratio that calculates the ratio of the company's stock price to the net book value per share. According to Tjiptono and Hendry (2001), PBV is a ratio that describes how much the market appreciates the value of a company's books. The higher this ratio means the market believes in the prospect of the company.

Some studies have been done before by Putra and Lestari (2016) which shows that ROA affects the value of the company. This is different from the research conducted by Putra, Chabachib, Haryanto and Pangestuti (2007) which show that ROA has no effect on company value. Research conducted by Mardiyati, Ahmad, and Putri (2012), shows that DER affects the value of the company. While research conducted by Rompas (2013), states that DER does not affect the value of the company. Research conducted by Putra and Lestari (2016), states that the Current Ratio effect on company value The different results are shown by Sudiani and Darmayanti (2016), which states that the Current Ratio has no effect on the value of the company.

Based on the background and inconsistency of the research mentioned above, the researcher is interested to re-examine the Influence of Profitability, Leverage and Liquidity to Company Value (Case Study of Manufacturing Company of Food and Beverage Sub Sector registered at Indonesia Stock Exchange 2010-2016 period).

\section{Research purposes}

1). To find out whether profitability affects the value of the company in manufacturing companies food and beverage sub-sector listed on the IDX period 2010-2016. 2). To determine whether leverage affects the value of the company in manufacturing companies food and beverage sub-sector listed on the IDX period 2010-2016. 3). To know whether liquidity affects the value of companies in manufacturing companies food and beverage subsector listed on the IDX 2010-2016 period.

\section{LITERATURE REVIEW}

The value of the company

According to Brigham and Ehrhardt (2014: 118), corporate value is the main objective of managerial decisions taking into account the risks and times associated with earnings forecasts for maximizing the company's common stock price. According to Gitman 
and Zutter (2015: 131), the value of the company provides an assessment of how investors see the company's performance. Companies are expected to earn relatively high returns on the risks they receive. Based on both definitions can be concluded that the value of the company is the fair value of a company that describes the perception or assessment of the success of a company that is always associated with stock prices.

\section{Price Book Value (PBV)}

The ratio of company value approach to be used in this research is Price Book Value (PBV). The definition of PBV according to Hery (2016: 27-28) is a ratio that shows the results of the comparison between the market price per share with the book value per share. This ratio is used to measure stock price level whether overvalued or undervalued. The lower the PBV of a stock, the share is categorized undervalued, which is very good for longterm investment. However, low PBV values may also indicate a decline in the quality and performance of the issuer's fundamentals. Therefore, PBV values must also be compared to other issuer's PBV shares in the same industry. If too much difference then it should be analyzed further.

\section{Profitabilitas}

According to Brigham and Ehrhardt (2014: 114), profitability ratios are considered important in determining a number of important policies and decisions within the company. This ratio is useful for knowing the company's operations, and the results of management. Profitability shows the combined effect of liquidity, management assets and operational debt. According to Gitman and Zutter (2015: 128), profitability ratios can be used to evaluate a company's profit by taking into account certain sales levels, certain asset levels or owner's investments. Without profit, a business can not spread out of capital. Owners, creditors, and management are paying attention to increasing profits because of the very importance of market share in revenue.

According to Kasmir (2016: 196), profitability ratio is the ratio to assess the ability of companies in the search for profit. This ratio also provides a measure of the level of management effectiveness of a company. This is shown by the profits generated from sales and investment income. The bottom line is the use of this ratio indicates the efficiency of a company.From the above definition can be concluded that profitability focuses on the ability of companies in generating profit or profit. The main purpose of a company is to obtain maximum profit or profit for investors. Every company wants a high level of profitability. In order to survive, the company must be in a favorable state. If the company is in an unfavorable condition, it will be difficult for the company to obtain investors. This situation will affect the stock price of the company. The ratio that shows profit for company used in this research is Return on Asset (ROA). ROA is a ratio to measure the overall effectiveness of management in generating profits with existing assets. The higher the company's return to total assets the better (Gitman, 2009: 68). The greater the ROA, the more efficient use of company assets or in other words with the same amount can be generated a large profit. With a high level of profit then the level of investor confidence will increase. 


\section{Leverage}

According to Brigham and Ehrhardt (2014: 109), the leverage ratio is the extent to which the company is financed with debt and the possibility of default on its debt obligations. According to Gitman and Zutter (2015: 124), leverage is the risk and return of the use of fixed costs, such as debt and preferred stock. The more fixed-cost debt the company uses, the greater the risk and the expected return. According to Kasmir (2016: 151), the ratio of leverage is the ratio used to measure the extent to which the company's assets are financed with debt. This means how much debt burden borne by the company compared to its assets. In a broad sense it is said that the leverage ratio is used to measure a company's ability to pay all its obligations, both short and long term if the company is dissolved (liquidated).

It can be concluded that leverage is the ratio used to measure the extent to which the company's assets are financed by debt. This means how much debt burden borne by the company compared to the assets owned by the company. The leverage ratio indicates the extent to which a company's ability to pay all its obligations, both short-term liabilities and long-term liabilities. Leverage will provide benefits to investors if the profit gained is greater than the fixed costs that must be issued by the company. On the other hand leverage can also increase the risk if the profit earned is lower than the fixed costs incurred.

The leverage ratio used in this research is Debt to Equity Ratio. According to Prastowo (2015: 79), in measuring risk, the focus of long-term creditors' attention is mainly shown on the earnings outlook and cash flow forecasts. Nevertheless, they can not ignore the importance of maintaining a balance between the proportion of assets funded by creditors and those funded by the owners of the company. The balance of proportion between creditor funded assets and those funded by company owners is measured by DER. According to Kasmir (2016: 166) Debt to Equity Ratio is the ratio used to determine the ratio of total debt with own capital. This ratio is useful to find out how much the company's assets are financed from debt. The bigger the DER then the greater the risk to the company. DER may indicate the risk factor that will be received by the investor and will affect the value of the company. Therefore, investors prefer stocks with low DERs.

\section{Liquidity}

According to Brigham and Ehrhardt (2014: 104), the Liquidity Ratio shows the relationship between the company's current assets and current liabilities in its ability to meet its maturing debts. According to Gitman and Zutter (2015: 119), the company's liquidity is measured by its ability to meet its short-term liabilities at maturity. According to Kasmir (2016: 151), liquidity ratio serves to indicate or measure the ability of the company to meet its obligations that have matured, both liabilities to outside parties (liquidity of business entities) and within the company (corporate liquidity). Thus it can be said that the usefulness of this ratio is to determine the company's ability to finance and meet the obligations (debt) when billed.

The ratio of liquidity used in this research is Current Ratio. Current Ratio is the ratio to measure a company's ability to pay short-term liabilities or debts that are due at the 
time of collection. (Kasmir, 2016: 146). The greater the Current Ratio the better, meaning the greater the ability of the company to pay the obligations immediately. Current Ratio compares all current assets with all liabilities immediately. From the results of the ratio measurement, if the ratio is smoothly low it can be said that the company is less capital to pay the debt. However, if the result of high ratio measurement, not necessarily condition of company is good. This can happen because cash is not being used as well as possible. In practice it is often used that the current ratio of $200 \%$ (2:1) standard is sometimes considered a good enough or satisfactory measure for a company. The above description can be formed the following concept framework:

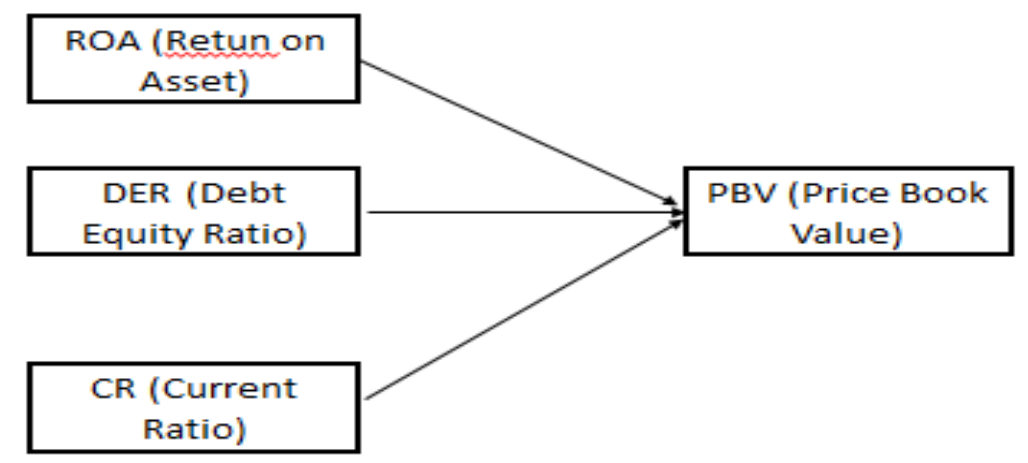

From the framework of research concepts can be drawn hypothesis as follows:

\section{Profitability}

According to Kasmir (2016: 196), profitability ratio is the ratio to assess the ability of companies in the search for profit. This ratio also provides a measure of the level of management effectiveness of a company. This is shown by the profits generated from sales and investment income. The bottom line is the use of this ratio indicates the efficiency of a company.From the above definition can be concluded that profitability focuses on the ability of companies in generating profit or profit. The main purpose of a company is to obtain maximum profit or profit for investors. Every company wants a high level of profitability. In order to survive, the company must be in a favorable state. If the company is in an unfavorable condition, it will be difficult for the company to obtain investors. This situation will affect the stock price of the company.The ratio that shows profit for company used in this research is Return on Asset (ROA). ROA is a ratio to measure the overall effectiveness of management in generating profits with existing assets. The higher the company's return to total assets the better (Gitman, 2009: 68). The greater the ROA, the more efficient use of company assets or in other words with the same amount can be generated a large profit. With a high level of profit then the level of investor confidence will increase. This will have an impact on the increase of company value. Therefore, the first hypothesis for this study is:

\section{H1:Return on Asset has an effect on company value.}

\section{Leverage}


According to Brigham and Ehrhardt (2014: 109), the leverage ratio is the extent to which the company is financed with debt and the possibility of default on its debt obligations. According to Gitman and Zutter (2015: 124), leverage is the risk and return of the use of fixed costs, such as debt and preferred stock. The more fixed-cost debt the company uses, the greater the risk and the expected return. According to Kasmir (2016: 151), the ratio of leverage is the ratio used to measure the extent to which the company's assets are financed with debt. This means how much debt burden borne by the company compared to its assets. In a broad sense it is said that the leverage ratio is used to measure a company's ability to pay all its obligations, both short and long term if the company is dissolved (liquidated).

It can be concluded that leverage is the ratio used to measure the extent to which the company's assets are financed by debt. This means how much debt burden borne by the company compared to the assets owned by the company. The leverage ratio indicates the extent to which a company's ability to pay all its obligations, both short-term liabilities and long-term liabilities. Leverage will provide benefits to investors if the profit gained is greater than the fixed costs that must be issued by the company. On the other hand leverage can also increase the risk if the profit earned is lower than the fixed costs incurred.

The leverage ratio used in this research is Debt to Equity Ratio. According to Prastowo (2015: 79), in measuring risk, the focus of long-term creditors' attention is mainly shown on the earnings outlook and cash flow forecasts. Nevertheless, they can not ignore the importance of maintaining a balance between the proportion of assets funded by creditors and those funded by the owners of the company. The balance of proportion between creditor funded assets and those funded by company owners is measured by DER. According to Kasmir (2016: 166) Debt to Equity Ratio is the ratio used to determine the ratio of total debt with own capital. This ratio is useful to find out how much the company's assets are financed from debt. The bigger the DER then the greater the risk to the company. DER may indicate the risk factor that will be received by the investor and will affect the value of the company. Therefore, investors prefer stocks with low DERs. Based on the above theory, the second hypothesis for this research is:

\section{H2 :Debt to Equity Ratio (DER) has an effect on company value.}

\section{Liquidity}

According to Brigham and Ehrhardt (2014: 104), the Liquidity Ratio shows the relationship between the company's current assets and current liabilities in its ability to meet its maturing debts. According to Gitman and Zutter (2015: 119), the company's liquidity is measured by its ability to meet its short-term liabilities at maturity. According to Kasmir (2016: 151), liquidity ratio serves to indicate or measure the ability of the company to meet its obligations that have matured, both liabilities to outside parties (liquidity of business entities) and within the company (corporate liquidity). Thus it can be said that the usefulness of this ratio is to determine the company's ability to finance and meet the obligations (debt) when billed. 
The calculation of the liquidity ratio provides enough benefits for various interested parties to the company. The most concerned parties are the owners of the company and the management of the company to assess their own abilities. Then, outside parties also have interests, such as creditors or providers of funds for companies, such as banking, or also the distributors or suppliers who distribute or sell goods that payments in installments to the company. This means that if the company experiencing liquidity kseulitan in the end the company will get a crisis of trust from various parties who have been helping smooth business. Therefore, the calculation of the liquidity ratio is not only useful for the company, but also for outsiders. In practice there are many benefits or objectives of the liquidity ratio analysis for the company, both for the owner of the company, and the parties that have relationships with companies such as creditors and distributors or suppliers.

The ratio of liquidity used in this research is Current Ratio. Current Ratio is the ratio to measure a company's ability to pay short-term liabilities or debts that are due at the time of collection. (Kasmir, 2016: 146). The greater the Current Ratio the better, meaning the greater the ability of the company to pay the obligations immediately. Current Ratio compares all current assets with all liabilities immediately. From the results of the ratio measurement, if the ratio is smoothly low it can be said that the company is less capital to pay the debt. However, if the result of high ratio measurement, not necessarily condition of company is good. This can happen because cash is not being used as well as possible. In practice it is often used that the current ratio of $200 \%$ (2:1) standard is sometimes considered a good enough or satisfactory measure for a company. Therefore, the third hypothesis for this study is:

\section{H3 :Current Ratio (CR) has an effect on firm value.}

\section{RESEARCH METHODS}

This research was conducted at Indonesia Stock Exchange through website www.idx.ac.id. The object of this research are financial ratios to company value and financial report data of food and beverage manufacturing companies listed on BEI period 2010-2016. Based on data from SahamOk, until 2016 there are 14 companies manufacturing food and beverage subsector listed on BEI. So the population for property and real estate companies are 14 companies. Sample determination method used in this research is sampling technique. The sampling technique used in this research is saturated sampling technique. A saturated sampling technique is a sample determination technique when all members of the population are used as a sample. The criteria in making this decision are:

1. The Company is included in a food and beverage sub-sector manufacturing company listed on the Indonesia Stock Exchange in 2010-2016.

2. Companies that publish financial statements during the study period take place in 20102016.

3. Companies that have complete data related to research during the period of research took place in the year 2010-2016. 
The data used in this study is quantitative data because the data measured in a numeric scale or number. The type of data used is secondary data. This data can be obtained through journals, books, libraries, articles, sites BEI www.idx.co.id and the official website of each company. The technique of collecting secondary data is using documentation method, ie data already available and can be directly or indirectly from source. In addition, researchers also obtained data collected from various literature studies, such as journals and information provided by the IDX website and the company's official website. Data used in this research is panel data, that is combination of cross-section data and time-series data.Independent variable of this research is Return on Asset (X1), Debt to Equity Ratio (X2), and Current Ratio (X3) while the dependent variable in this research is Price Book Value (Y). Analyzer used in this research is Classical Assumption Test, Determination Coefficient Test and Hypothesis Testing. This test aims to take a decision in solving the problem so that it can be drawn a conclusion and test whether the formulated hypothesis is rejected or accepted.

\section{FINDINGS AND DISCUSSION}

\section{Testing classical assumptions}

Classic assumption test is divided into 3 tests, namely:

\section{Normality test}

The normality test referred to in the classical assumption of the OLS approach is the residual data formed by the normal distributed linear regression model, not the independent variable or the dependent variable. The decision to be normally distributed or not to residuals is to compare the Jarque-Bera probability value with an alpha level of $0.05(5 \%)$. The value of JB prob probes $0.344432>0.05$ so it can be concluded that the residual is normally distributed which means the classical assumption about normality has been met.

\section{Heteroscedasticity Test}

Heterocedasticity occurs at the time of residual and the predicted value has a correlation or relationship pattern.

Table 1. Heteroscedasticity test using Glejser Test

Heteroskedasticity Test: Glejser

\begin{tabular}{llll}
\hline \hline F-statistic & 1.066669 & Prob. F(3,52) & 0.3713 \\
Obs*R-squared & 3.246385 & Prob. Chi-Square(3) & 0.3552 \\
Scaled explained SS & 2.459075 & Prob. Chi-Square(3) & 0.4827 \\
\hline \hline
\end{tabular}

Decision of whether or not heterokedastisitas is to see the prob. F-statistic (F Count) if the value of prob. F Calculate 0.3713 greater than alpha level 0.05 (5\%) so, it can be concluded that there is no heterokedastisitas.

\section{Multicolinearity Test}

Multicollinearity test aims to test whether the regression model found a high or perfect correlation between independent variables (independent). 
Multicollinearity test results, can be seen in the table centered column VIF. The decision of whether or not multicollinearity occurs if the VIF value is no greater than 10. In this table the VIF value for ROA is 1.087059 , the VIF value for DER is 3.032144 and the VIF value for CR is 2.947702. Since the VIF value of the three variables is not greater than 10 , it can be said that there is no multicollinearity in the three independent variables.

\section{Estimation of Panel Data Model}

Estimation of panel data model there are three approaches are: Common Effect Method, Fixed Effect Method and Random Effect Method. All three of these approaches will be selected that best suit using the Chow Test and Hausman Test. After the selected test is the estimation of panel data model by using fixed effect method.

\section{Data analysis}

Data analysis consists of: Simultaneous Test (Test Statistic F), Partial Test (T Test Statistic), and Coefficient of Determination R2

\section{Simultaneous Test (Test Statistic F)}

The F statistic test is the initial step of identifying the estimated regression model is feasible or not. Worthy here means the model is estimated to be eligible to explain the effect of the independent variables on the dependent variable. If the value is prob. F count is smaller than the error rate then it can be said that the regression model is estimated to be feasible. Whereas if prob. F calculate greater than the error rate then it can be said that the regression model is not feasible.

\section{Here are the results Test statistics F:}

Effects Specification

\begin{tabular}{lcll}
\hline \hline \multicolumn{4}{c}{ Cross-section fixed (dummy variables) } \\
\hline \hline R-squared & 0.886575 & Mean dependent var & 1.413320 \\
Adjusted R-squared & 0.861369 & S.D. dependent var & 1.015566 \\
S.E. of regression & 0.378127 & Akaike info criterion & 1.066997 \\
Sum squared resid & 6.434114 & Schwarz criterion & 1.464834 \\
Log likelihood & -18.87591 & Hannan-Quinn criter. & 1.221237 \\
F-statistic & 35.17373 & Durbin-Watson stat & 1.354491 \\
Prob(F-statistic) & 0.000000 & & \\
\hline \hline
\end{tabular}

In the table above the prob. $F$ of 0,000000 less than the error rate of 0.05 so it can be concluded that the estimated regression model is feasible to be used to explain the effect of profitability (ROA), leverage (DER) and liquidity (CR) to firm value (PBV).

\section{Partial Test (T Test Statistic)}

The stastitic $\mathrm{T}$ test is basically to show how far the influence of one independent variable is individually in explaining the dependent variable. If the value is prob. T arithmetic smaller than the error rate then it can be said that independent variables significantly affect 
the dependent variable. Whereas if prob. T calculate greater than the error rate then it can be said that the independent variable has no significant effect on the dependent variable. Here are the results Test statistics Q:

\begin{tabular}{crrrr}
\hline \hline Variable & Coefficient & Std. Error & t-Statistic & Prob. \\
\hline \hline LOG(ROA) & 0.485999 & 0.191359 & 2.539720 & 0.0146 \\
LOG(DER) & 0.356487 & 0.202472 & 1.760675 & 0.0139 \\
LOG(CR) & -0.175375 & 0.273425 & -0.641401 & 0.5245 \\
C & 1.287452 & 1.514920 & 0.849848 & 0.3999 \\
\hline
\end{tabular}

Based on the above table, then the conclusions that can be drawn from this analysis are as follows:

\section{H1: Return on Asset has an effect on company value.}

In the table above, we get the prob. $\mathrm{T}$ for profitability (ROA) of 0.0146 . Which means prob value. $\mathrm{T}(0.0146)$ is smaller than the error rate $(0.05)$. Then obtained the conclusion that the variable profitability (ROA) have a significant effect on the variable value company (PBV).

\section{H2: Debt to Equity Ratio (DER) has an effect on company value.}

In the table above, we get the prob. T for leverage variable (DER) of 0.0139. Which means prob value. $\mathrm{T}(0.0139)$ is smaller than the error rate $(0.05)$. Then obtained the conclusion that the leverage variable (DER) has a significant effect on the variable of firm value $(\mathrm{PBV})$.

\section{H3: Current Ratio (CR) has an effect on company value.}

In the table above, we get the prob. $\mathrm{T}$ for the liquidity variable (CR) of 0,5245. Which means prob value.T (0.5245) greater than the error rate (0.05). Then obtained the conclusion that the liquidity variable $(\mathrm{CR})$ has no significant effect on the variable of firm value $(\mathrm{PBV})$.

\section{Determination Coefficient Test (R2)}

Coefficient of Determination (R2) describes the variation of the influence of independent variables on the dependent variable. Or it can also be said as the proportion of influence of all independent variables on the dependent variable. Here are the results of Coefficient of Determination Test (R2): 


\section{Effects Specification}

\begin{tabular}{lcll}
\hline \hline \multicolumn{4}{c}{ Cross-section fixed (dummy variables) } \\
\hline \hline R-squared & 0.886575 & Mean dependent var & 1.413320 \\
Adjusted R-squared & 0.861369 & S.D. dependent var & 1.015566 \\
S.E. of regression & 0.378127 & Akaike info criterion & 1.066997 \\
Sum squared resid & 6.434114 & Schwarz criterion & 1.464834 \\
Log likelihood & -18.87591 & Hannan-Quinn criter. & 1.221237 \\
F-statistic & 35.17373 & Durbin-Watson stat & 1.354491 \\
Prob(F-statistic) & 0.000000 & & \\
\hline \hline
\end{tabular}

In the table above, the adjusted R-squared value is 0.861369 indicating that the proportion influence of profitability (ROA), leverage (DER) and liquidity (CR) to company value (PBV) is $86 \%$. While the rest of $14 \%$ influenced by other variables that do not exist in the regression model.

\section{CONCLUSION AND SUGESTION}

The results of this study aims to provide evidence of the significant effect of return on asset and debt to equity ratio on firm value. While the variable current ratio does not significantly affect the value of the company. For food and beverage manufacturing companies, the liquidity projected by Current Ratio does not affect investor interest in the valuation of a share. Because investors are more looking at the company's business activities without seeing the company's liquidity. So from this research shows that liquidity is not used by investors as a consideration in investing in the company.

This research has several limitations, ie the Company which is the only research sample of food and beverage sub-sector manufacturing company that listed on Indonesia Stock Exchange 2010-2016 period. Accordingly, the results obtained in this study can not represent value for all manufacturing firms. The observation period of the study was limited to only seven years ie 2010-2016. Thus the results obtained in this study can not represent the value for the previous or next period. The dependent variable or dependent variable used in this study is Price Book Value. Independent variables or independent variables in the study using only 3 variables of Return on Assets, Debt to Equity Ratio and Current Ratio.

\section{REFERENCE}

Anwar, Sanusi, (2011). Business Research Methods, Jakarta: Salemba Empat.

Arikunto, Suharsimi. (2010). Research Procedures A Practice ApproachJakarta: Rineka Cipta.

Asnawi and Wijaya. (2015). Financial Research Empirical Testing.Jakarta: Gramedia Pustaka Utama.

Brigham, E.F. and Ehrhardt, M.C., (2014). Financial Management Theory and Practice. 13th Edition. South Western International Student Edition: Ohio.

Fahmi, Irham. (2012), Financial Statement Analysi,.Bandung: Alfabeta. 
Ghozali, I. \& Ratmono, D. (2013). Multivariate Analysis and Econometrics Theory, Concepts, and Applications with EViews 8.Semarang: Diponegoro University Publishing Agency.

Gitman, J.L \& Zutter, C.J. (2012).Principle of Managerial Finance. 13th Edition. England: Pearson.

Hasibuan, Malayu S.P. (2011). Banking Basics.Jakarta: Bumi Aksara

Kasmir.(2016). Financial Statement Analysis. Jakarta: Raja Grafindo Persada.

Mardiyati, Umi, Gatot, Nazir Ahmad and Ria Putri. (2012). Influence of Dividend Policy, Debt Policy and Profitability to Value of Manufacturing Company Listed In Indonesia Stock Exchange (BEI) Period 2005-2010Jakarta: Jurnal Riset Manajemen Sains Indonesia (JRMSI) Vol. 3, No.1 (2012).

Martono and Harjito.(2010). Financial management.Edisi 3. Yogyakarta: Ekonisia

Putra, AA Ngurah Dharma Adi Putra \& Lestari.(2016). Influence of Dividend Policy, Liquidity, Profitability, and Company Size on Company Value.E-Jurnal Manajemen Unud, Vol. 5 No. 7 (2016).

Putra, Tito Perdana, M Chabachib, dkk.(2007). The Effect of Financial Performance and Stock Beta on Price To Book Value (Study on Real Estate Companies and Listed Properties In Indonesia Stock Exchange Period Year2004-2006. Semarang.Jurnal Studi Manajemen \& Organisasi Vol. 4 No. 2 (2007).

Rompas, Gisela Prisilia. (2013). Liquidity, Solvency, and Rentability To The Value Of BUMN Companies Listed In Indonesia Stock Exchange. Manado. Jurnal EMBA Vol. 1 No. 3 (2013).

Sartono, Agus. (2008). Financial Management Theory and Applications Fourth Edition. Yogyakarta: BPFE.

Sudana, I Made. (2011). Corporate Finance Management Theory \& Practice.Jakarta: Erlangga.

Sudiani, Ni Kadek Ayu and Darmayanti. (2016). The Effect of Profitability, Liquidity, Growth and Investment Opportunity Set Of Company Value. E-Jurnal Manajemen Unud, Vol. 5 No. 7 (2016).

Sugiyono (2009). Quantitative Research Methods, Qualitative and Research and Development. Bandung: Alfabeta.

Sugiyono. (2013). Quantitative Research Methods, Qualitative and Research and Development. Bandung: Alfabeta.

Widarjono, Agus. (2013). Econometric: Introduction and aplication. Jakarta: Ekonisia. 